\title{
Key Reform Task Identification Model for State-owned Large-scale Power Grid Enterprise in China
}

\author{
Song XUE*, Xiao-Bin LIN, Fan ZHANG, Jian-Hui LIAO, Ze-Chen WU, Li MA \\ and Yuan $\mathrm{HU}$
}

State Grid Energy Research Institute Company Limited, Beijing 102209, China

*xuesongbjhd@163.com

Keywords: State-owned large-scale power grid enterprise, State-owned assets and enterprises reform, Power system reform, Key reform task identification.

\begin{abstract}
In view of reform tasks that state-owned large-scale power grid enterprises need to implement in aspects of state-owned assets and enterprises reform, power system reform and enterprise internal management reform, a key task identification model covering continuity degree of influence, national requirement degree, social concern degree, urgency degree of enterprise needs is constructed. Identifying reform tasks that state-owned large-scale power grid enterprises need to focus on and promote, specifically including mixed ownership reform, power transmission and distribution tariff reform, power market construction, incremental power distribution reform, the optimization of the system and mechanism of power grid business, internal classification reform, the formation and standard operation of power trading institution, reform of three systems.
\end{abstract}

\section{Introduction}

State-owned large-scale power grid enterprises are basic industries that related to the lifeblood and energy security of national economy and society. Under the background of comprehensively deepening reform, as the leading entity of industry, state-owned large-scale power grid enterprises are the objection of reform, also main market entity that carry out state-owned assets and enterprises reform, power system reform tasks[1]. It is urgent to construct an identification model of major reform tasks for state-owned large-scale power grid enterprises, identifying the importance and continuity of reform tasks, providing decision support for adopting adaptive strategy.

At present, there are few studies on key reform task for large state-owned power grid enterprises, mainly focused on the impact of reform policies on power grid enterprises and the way of implementation in the future[2,3]. Firstly, the reform situation and requirements faced by large state-owned power grid enterprises were analyzed, and key reform task identification model was constructed and a case analysis was carried out.

\section{Reform Situation and Requirements Faced by Large State-Owned Power Grid Enterprises}

The power system reform has entered a stage of full acceleration, transmission and distribution tariff reform is about to be completed, incremental distribution and power market construction has attracted much attention, which required large-scale power grid enterprises to achieve high quality development, enhance competitiveness and service levels, promote clean energy consumption and release reform dividends.

State-owned assets and enterprises reform has stepped into the stage of expansion and deepening from a single pilot to a comprehensive pilot, and has become a breakthrough point of reform. The pressure of large-scale power grid enterprise has increased sharply, required positive response and initiative to promote the establishment of an institutional mechanism suitable for marketization. At present, the first batch and the second batch of 19 mixed ownership reform pilot projects have entered the stage of implementation, a total of more than 40 investors and more than 90 billion yuan of capital were introduced in 2017. Among them, China Unicom, Eastern Airlines, Sinopec and other central enterprises mixed ownership reform has received extensive social impact, 
while state-owned large-scale power grid enterprises are relatively slow in progress and face greater external pressure.

The problem of not adapting to marketization in state-owned large-scale power grid enterprises is becoming increasingly prominent, in which the rigid mechanism and the human resources management have become the development bottleneck. State-owned large-scale power grid enterprises are required to rely on reform to establish a more efficient and scientific system and business layout lay a solid foundation for the new development strategy.

Overall, state-owned large-scale power grid enterprises are facing increasingly urgent reform situation. The central government attaches great importance to and constantly puts forward higher requirements. The reform is advancing in depth and new situations are emerging. The society has been widely focused and continuously showing high expectations. State-owned power grid enterprises are entering a critical stage of comprehensive and deepening reform. It is urgent to strengthen top-level design, plan reform strategy, intensify reform efforts and create reform highlights.

\section{Key Reform Task Identification Model}

\section{Key Reform Task Measurement Dimension}

State-owned large-scale power grid enterprises are key state-owned enterprises which are related to the lifeline of national economy and national energy security. Key reform tasks of whom are characterized by higher continuity degree of influence, national requirement degree, social concern degree and urgency degree of enterprise needs.

Continuity degree of influence: From the time dimension, reform tasks can be proceed in the near future and in the long run.

National requirement degree: Reform tasks which belong to the state's key concern, can be measured by the level and frequency of relevant policy issuance.

Social concern degree: Tasks of reform which can arouse widespread concern and benefit the society. It can be measured by the concern degree of public opinion and the sense of reform effect.

Urgency degree of enterprise needs: Reform tasks that can promote high quality and orderly development of state-owned large-scale power grid enterprises. It can be measured by the reform cost and influence degree of operation service performance.

\section{Identification Model}

Continuity degree of influence: The continuity index of reform tasks, part reform tasks are phased tasks, which can be completed in a short time and then the specification can be executed; part reform tasks are long-run implementation, dynamic adjustment and optimization tasks. We should focus on reform tasks with strong continuity.

Importance degree of impact: Importance indicators of reform tasks, from the state requirements, social concerns, power grid enterprise itself needs these three key measurement elements, according to the importance degree of impact set three levels- $\boldsymbol{H}$ higher level, $\boldsymbol{M}$ medium level, $\boldsymbol{L}$ general level. The reform tasks of $\mathbf{3 H}(\mathrm{HHH}), \mathbf{2 H 1} \boldsymbol{M}$ (HHM, HMH, MHH) and 1H2M (HMM, MHM, MMH) labels mean that from the national, social and enterprise itself three perspectives, they are extremely important to at least one perspective, and the other two perspectives are relatively important, which are listed as reform tasks that need to be promoted in the near future.

\section{Case Study}

Main reform tasks and assessment results faced by state-owned large-scale power grid enterprises are shown in Table1. 
Table 1 State-owned large-scale power grid enterprises reform task and diagnosis identification results

\begin{tabular}{|c|c|c|c|c|c|c|}
\hline \multirow{2}{*}{ 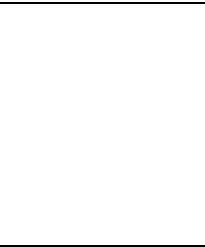 } & \multirow{2}{*}{ Reform tasks } & \multicolumn{2}{|c|}{$\begin{array}{l}\text { Continuity degree of } \\
\text { influence }\end{array}$} & \multicolumn{3}{|c|}{ Importance degree of impact } \\
\hline & & & & National & Social & Urgency \\
\hline \multirow{7}{*}{$\begin{array}{l}\text { State-owned } \\
\text { enterprise } \\
\text { reform }\end{array}$} & $\begin{array}{l}\text { State-owned enterprise } \\
\text { classification reform }\end{array}$ & $\sqrt{ }$ & $\sqrt{ }$ & $\mathbf{M}$ & $\mathbf{L}$ & $\mathbf{M}$ \\
\hline & $\begin{array}{l}\text { Improving the modern enterprise } \\
\text { system }\end{array}$ & $\sqrt{ }$ & & $\mathbf{M}$ & $\mathbf{L}$ & $\mathbf{L}$ \\
\hline & $\begin{array}{l}\text { Improving the state-owned } \\
\text { assets management system }\end{array}$ & $\sqrt{ }$ & & $\mathbf{M}$ & $\mathbf{L}$ & $\mathbf{L}$ \\
\hline & $\begin{array}{l}\text { Central enterprise structure } \\
\text { adjustment and restructuring }\end{array}$ & $\sqrt{ }$ & $\sqrt{ }$ & $\mathbf{M}$ & $\mathbf{L}$ & $\mathbf{L}$ \\
\hline & Mixed ownership reform & $\sqrt{ }$ & $\sqrt{ }$ & $\mathbf{H}$ & $\mathbf{H}$ & $\mathbf{H}$ \\
\hline & $\begin{array}{l}\text { Strengthening the supervision of } \\
\text { preventing the loss of state assets }\end{array}$ & $\sqrt{ }$ & $\sqrt{ }$ & $\mathbf{M}$ & $\mathbf{L}$ & $\mathbf{M}$ \\
\hline & $\begin{array}{l}\text { Accelerating the social function } \\
\text { divestiture of corporates and the } \\
\text { solution of historical problems }\end{array}$ & $\sqrt{ }$ & & $\mathbf{M}$ & $\mathbf{L}$ & $\mathbf{M}$ \\
\hline \multirow{7}{*}{$\begin{array}{l}\text { Power } \\
\text { system } \\
\text { reform }\end{array}$} & $\begin{array}{l}\text { Transmission and distribution } \\
\text { tariff reform }\end{array}$ & $\sqrt{ }$ & $\sqrt{ }$ & $\mathbf{H}$ & $\mathbf{H}$ & $\mathbf{H}$ \\
\hline & Electricity market construction & $\sqrt{ }$ & $\sqrt{ }$ & $\mathbf{H}$ & $\mathbf{H}$ & $\mathbf{H}$ \\
\hline & $\begin{array}{l}\text { Establishment and standard } \\
\text { operation of power trading } \\
\text { institutions }\end{array}$ & $\sqrt{ }$ & $\sqrt{ }$ & $\mathbf{M}$ & $\mathbf{H}$ & $\mathbf{M}$ \\
\hline & $\begin{array}{l}\text { Orderly development of } \\
\text { electricity generation and } \\
\text { consumption plans }\end{array}$ & $\sqrt{ }$ & & $\mathbf{L}$ & $\mathbf{M}$ & $\mathbf{L}$ \\
\hline & Electricity sales side reform & $\sqrt{ }$ & $\sqrt{ }$ & $\mathbf{M}$ & $\mathbf{M}$ & $\mathbf{M}$ \\
\hline & $\begin{array}{l}\text { Incremental power distribution } \\
\text { reform }\end{array}$ & $\sqrt{ }$ & $\sqrt{ }$ & $\mathbf{H}$ & $\mathbf{H}$ & $\mathbf{H}$ \\
\hline & $\begin{array}{l}\text { Strengthening and standardizing } \\
\text { the supervision and management } \\
\text { of coal-fired and self-owned } \\
\text { power plants }\end{array}$ & $\sqrt{ }$ & & $\mathbf{L}$ & $\mathbf{M}$ & $\mathbf{M}$ \\
\hline \multirow{7}{*}{$\begin{array}{l}\text { Enterprise } \\
\text { internal } \\
\text { management } \\
\text { reform }\end{array}$} & Internal classification reform & $\sqrt{ }$ & & $\mathbf{M}$ & $\mathbf{H}$ & $\mathbf{H}$ \\
\hline & Collective enterprise slimming & $\sqrt{ }$ & & $\mathbf{L}$ & $\mathbf{M}$ & $\mathbf{H}$ \\
\hline & Reform of three systems & $\sqrt{ }$ & $\sqrt{ }$ & $\mathbf{M}$ & $\mathbf{M}$ & $\mathbf{H}$ \\
\hline & $\begin{array}{l}\text { Optimization of the system and } \\
\text { mechanism of power grid } \\
\text { business }\end{array}$ & $\sqrt{ }$ & $\sqrt{ }$ & $\mathbf{H}$ & $\mathbf{H}$ & $\mathbf{H}$ \\
\hline & $\begin{array}{l}\text { Accelerating new business } \\
\text { development }\end{array}$ & $\sqrt{ }$ & $\sqrt{ }$ & $\mathbf{M}$ & $\mathbf{L}$ & $\mathbf{H}$ \\
\hline & $\begin{array}{l}\text { Comprehensively strengthening } \\
\text { risk prevention and control }\end{array}$ & $\sqrt{ }$ & $\sqrt{ }$ & $\mathbf{M}$ & $\mathbf{L}$ & $\mathbf{H}$ \\
\hline & $\begin{array}{l}\text { The separation and handover of } \\
\text { water supply, power supply, } \\
\text { heating and property } \\
\text { management }\end{array}$ & $\sqrt{ }$ & & $\mathbf{L}$ & $\mathbf{L}$ & $\mathbf{H}$ \\
\hline
\end{tabular}

\section{(1) Continuity Degree of Influence}

Continuing reform tasks include:

State-owned enterprise reform — state-owned enterprise classification reform, central enterprise structure adjustment and restructuring, mixed ownership reform, and strengthening the supervision of preventing the loss of state assets. 
Power system reform-transmission and distribution tariff reform, electricity market construction, establishment and standard operation of power trading institutions, and incremental power distribution reform.

Enterprise internal management reform - reform of three systems(refers to the reform of labor, personnel and distribution system), the optimization of the system and mechanism of power grid business, accelerating new business development, and comprehensively strengthening risk prevention and control.

\section{(2) Importance Degree of Impact}

By investigating relevant experts in the fields of state-owned enterprises, power system reform, and enterprise management, the values of various reform tasks are assigned.

3H: Mixed ownership reform, transmission and distribution tariff reform, Electricity market construction, Incremental power distribution reform and the optimization of the system and mechanism of power grid business.

2H1M: Internal classification reform.

1H2M: Establishment and standard operation of power trading institutions, and the reform of three systems.

Through cross checking, it shows that the reform tasks with high importance are generally with stronger continuity, which have certain dynamic optimization and uncertainty. Only enterprise internal management reform is concentrated recently. But the optimization development of competitive business in the internal classification reform has some certain continuity characteristics, it is also included in the key promotion scope. The specific comparison results are shown in Figure 1.

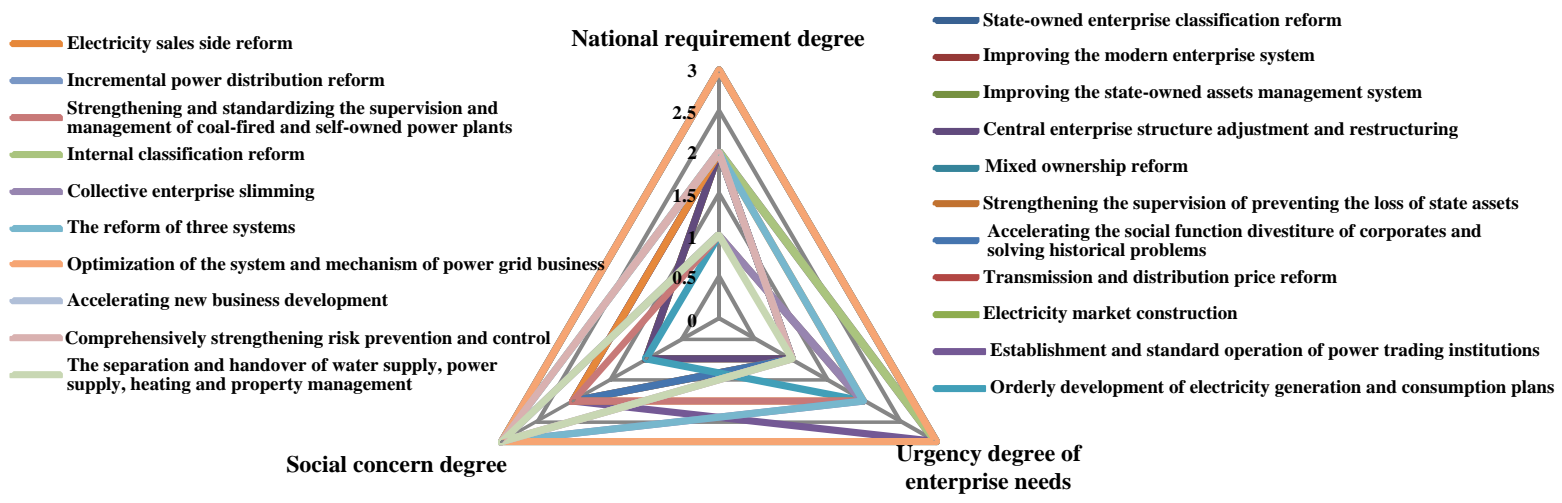

Fig. 1 Comparison of reform tasks’ importance degree of impact

Mixed ownership reform(3H): The state specially promulgated the document No. 54 of the State Council [2015] to promote mixed reform, with the highest number of supporting documents and the superior level. From the perspective of social concerns, the mixed ownership reform is the focus of central enterprises reforms in the past five years; For state-owned large-scale power grid enterprises, the cost of mixed ownership reform is relatively low, which will help improve the operating performance of state-owned large-scale power grid enterprises.

Transmission and distribution tariff $\operatorname{reform}(3 \mathbf{H})$ : The state specially promulgated the document No. 9 and No. 28 of the Central Committee of the Communist Party of China[2015], constructing the basic framework of transmission and distribution price regulatio, and these documents are with high level. The society has expectations for lowering electricity costs through adjusting transmission and distribution prices. Significant changes have taken place in the profit model and the supervision method of the state-owned large-scale power grid enterprises, which has a great impact on the strategic positioning, development concept, business layout, organizational structure, business management methods and operational processes of state-owned large-scale power grid enterprises. In June 2017, the power transmission and distribution price approval for the first regulatory period of the provincial power grid was completed (except Tibet). 
Electricity market construction(3H): Regarding market mechanism role in allocation of power resources, the government has issued various guidance and methods. The society pays close attention to spot transactions, etc., and it is urgent to reduce the cost of energy consumption through market transactions; State-owned large-scale power grid enterprises urgently need to speed up market construction to ease the pressure of electricity price reduction and new energy consumption.

Incremental power distribution reform(3H): The relevant state departments intensively issued documents for accelerating incremental power distribution reform, convened three special work meetings to deploy relevant work, and proposed that accountability investigations should be initiated for the first batch of projects with slow progress; the participation of relevant entities in the society is highly motivated. The participation of state-owned large-scale power grid enterprises in pilot projects is of great significance for ensuring revenue and promoting unified management of distribution networks and quality services.

Optimization of the system and mechanism of power grid business(3H): The grid business system and mechanism involves business environment, basic support ability for economic and social development, for which the national leaders have deployed tasks several times. Users are more interested in providing personalized and high-quality services; achieving grid business quality and efficiency improvement is also the goal pursued by state-owned large-scale power grid enterprises.

Internal classification reform(Competitive business)(2H1M): Market entities are more concerned about the classification reform of state-owned large-scale power grid enterprises and the achievement of fair competition in competitive business. For state-owned large-scale power grid enterprises, accelerating the development of competitive businesses is also an urgent need to release development vitality and potential, as well as foster new profit growth points.

Establishment and standard operation of power trading institutions(1H2M): All parties in the society pay close attention to the actual operation effect of trading institutions of different formation methods, and the evaluation work of the operation effect of the trading institutions is about to start.

The reform of three systems(1H2M): It is an important task for state-owned large-scale power grid enterprises to solve the current employment conflicts, tap the potential of existing human resources, and improve the vitality and power of enterprise development.

\section{Conclusion}

For large-scale and state-owned power grid companies, the key reform tasks include mixed ownership reform, power transmission and distribution tariff reform, power market construction, incremental power distribution reform, the optimization of the system and mechanism of power grid business, internal classification reform, the formation and standard operation of power trading institution, along with reform of three systems. In future, the problems arising in the advancement of the corresponding reform tasks should be prioritized to solve, and the key areas of reform should be tilted in the internal resource allocation of enterprises.

\section{Acknowledgement}

This work was supported by science and technology project of STATE GRID Corporation of China "Research on Evaluation Technology and Analysis Model of Electricity Retail Market Competitiveness”.

\section{References}

[1] GE Rui, CHEN Longxiang, WANG Yiyu, Optimization and Design of Construction Route for Electricity Market in China, Automation of Electric Power Systems, 41(24) 10-15.

[2] MA Li, HUANG Liming, XUE Song, FAN Menghua, ZHANG Xiaoxuan, Key Issues for Orderly Operation of China’s New Electricity Market Reform Pilot, Electric Power, 50(4): 17-22. 
[3] ZHANG Lizi, XU Chuanlong, Electricity Market Construction Experience of Major Provinces of Energy in China, Electric Power, 50(4): 7-10. 